\title{
Offshore wind-turbine structures: a review
}

1 Muhammad Arshad MSc, ME

PhD candidate, Department of Civil, Structural and Environmental Engineering, Trinity College Dublin, Ireland; Lecturer, Department of Geological Engineering, University of Engineering and Technology, Lahore, Pakistan
2 Brendan C. O’Kelly PhD, FTCD, CEng, CEnv, MICE

Associate Professor, Department of Civil, Structural and Environmental Engineering, Trinity College Dublin, Ireland
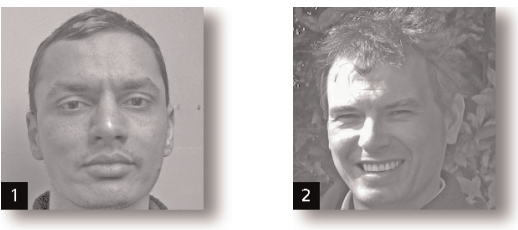

This paper reviews various issues related to wind-power generation, one of the more popular forms of renewable energy, including attractions and challenges of electric power generation through onshore and offshore resources. Significant increases in wind-turbine dimensions, rated power-generation capacity and size of wind farm developments over the past two decades are projected to continue. Offshore wind-power generation presents many engineering challenges including: limited guidelines available for analysis and design of foundation/support structures; inadequate logistics for construction/fabrication; and comparatively expensive operation and maintenance costs, which combined result in current levelised cost of energy approximately double that for onshore wind-power generation. Different offshore foundation options are discussed in terms of general layout, loading characteristics and related fundamental natural frequency. Outlooks for some new approaches/developments and areas for further research are identified that may go towards reducing the levelised cost of energy for wind-power generation more in line with that from other energy resources, thereby enhancing the attractiveness of this industry for potential investors.

\section{Notation}

A scalar

EI bending stiffness

$f_{\text {nat }} \quad$ first natural frequency

$f_{\text {wind }}$ probability density function

$k \quad$ shape factor quantifying width of wind-speed distribution

$L \quad$ strut length

$M \quad$ turbine mass

$\bar{U}_{10}$ wind speed at $10 \mathrm{~m}$ elevation above mean sea level or typically at hub height for OWTs

$\bar{U}_{z} \quad$ mean wind speed at elevation $\mathrm{z}$ above mean sea level

$1 \mathrm{P}$ first excitation frequency

3P blade passing frequency for three-bladed turbine

$\alpha \quad$ scalar

$\mu \quad$ strut mass per unit length

$v \quad$ Weibull random variable

\section{Introduction}

Wind-power turbines harness the kinetic energy of the wind, providing the motive force to rotate turbine blades and develop, by way of a drive shaft, the mechanical power to generate electricity. Wind turbines are categorised by axis of rotation of the main rotor shaft (either horizontal or vertical axis) and whether they are located onshore or offshore (Tong, 2010). For modern commercial wind turbines, the main rotor shaft is horizontally aligned. Rated power-generation capacity is mainly dependent on rotor diameter and wind speed (IRENA, 2012); for example, if wind speed increases two-fold, its energy content increases eight-fold. Two key speed terms are 'cut-in speed', at which the wind turbine begins to produce power, and 'cut-out speed' at which the turbine must be shut down to protect the rotor and drive-train machinery from possible damage (Sørensen et al., 2009; Tong, 2010).

Between 2000 and 2011, global wind-power capacity approximately doubled every 3 years, with an estimated total power generation of $238 \mathrm{GW}$ achieved by the end of 2011; China, the USA and Germany are the top industry players (GWEC, 2011). Although the market is still dominated by onshore, with significant onshore wind resources yet to be explored, the offshore wind market is growing rapidly. Global total installed capacity for offshore of $3 \cdot 12 \mathrm{GW}$ was generated by the end of 
2010, with $1.16 \mathrm{GW}$ added in 2010 alone - a 59.4\% increase on the previous year (WWEA, 2011). Total offshore wind-power capacity in Europe reached $2.90 \mathrm{GW}$ by the end of 2010, with $0.88 \mathrm{GW}$ added in 2010; again this represents a significant increase of $43.6 \%$ on the previous year. This occurred at the same time as onshore new-capacity additions declined by $13 \%$ (WWEA, 2011).

The size of offshore wind farms is also increasing, with 2010 data indicating that the average size of an offshore wind farm in terms of power output was $155 \mathrm{MW}$ - more than double the average wind farm size of $72 \mathrm{MW}$ for 2009 (EWEA, 2011). Preliminary data for 2011 suggest that offshore windpower capacity in Europe increased by $0.86 \mathrm{GW}$ (EWEA, 2012), with the offshore market likely to be driven by mainly the UK and Germany, although France and Sweden also have significant projects imminent. Collectively the European Union (EU) has plans to generate approximately $40 \mathrm{GW}$ from offshore wind by 2020 (EWEA, 2009). In its 2008 communication on offshore wind energy, the European Commission anticipated offshore wind can and must make a substantial contribution to meeting the EU's energy policy objectives through a very significant increase - in the order of 30 to 40 times by 2020 and 100 times by 2030 - in installed capacity compared to today (ECN, 2011a).

Interest in offshore wind power is also increasing in other regions of the world, with, for example, China, the USA and South Korea planning to generate 6.0 and $3.0,2.5 \mathrm{GW}$, respectively, by 2020. Building on this, China and the USA have ambitious plans to generate 65 and $54 \mathrm{GW}$, respectively, from offshore wind by 2030 (AWEA, 2012; Musial and Bonnie, 2010).

A significant hurdle for the offshore market, however, is the high initial capital investment costs of the project, which is related to: inadequate and (or) potentially unreliable design guidelines for offshore wind-turbine (OWT) installations, especially foundation structures; more stringent requirements for durable construction materials to withstand the harsh marine environment; high-tech equipment requirements for on-site operation and also shortage of trained manpower (Musial and Bonnie, 2010). In addition, the next generation of OWTs will be installed at greater distances offshore and hence in greater water depths (see Section 4). Compared with onshore, attractions of offshore wind-power generation generally include: longer life-span of OWTs on account of less fluctuation of wind speed; availability of ample free space for installation; consistently higher wind speeds and generally reduced adverse environmental effects (Damien and Mo, 2002).

This review paper considers the following aspects of the wind industry
- trends in geometric size and rated power-generation capacity of onshore and offshore wind turbines

- cost analyses

- different foundation options available, including features of exemplary structures, with particular focus on OWT structures

- challenges and attractions of wind-power generation.

Recommendations for future research and practice are also proposed to make offshore wind energy comparable with other sources of renewable energy.

\section{Trends in geometric size and rated power capacity of offshore wind turbines}

Figure 1(a) shows the main components of an OWT system, including a typical monopile foundation, the substructure, transition piece, tower, rotor blades and nacelle (hub). Modern OWTs are installed with either pitch-regulated blades or variable rotational speed systems in order to allow optimisation of power production over a wide range of prevailing wind speeds. The rotational speed of the main rotor shaft is typically between 10 and $20 \mathrm{rpm}$ (Alderlieste, 2010; Malhotra, 2011). The nacelle (Figure 1(b)) contains key electromechanical components of the wind turbine, including the gearbox and generator. Operational details of these components have been reported by Maria (2009) and Tong (2010). The gearbox may cause efficiency losses for the wind turbine and is a particular source of noise. Recent developments in the design of permanent magnet generators have made it possible to construct some types of wind turbines without the requirement for a gearbox. In this case, the rotor is connected directly to a lowspeed multi-pole generator that rotates at the same speed, termed a direct-drive unit. Removing the gearbox removes one of the key components requiring more maintenance and that is prone to failure. This simplification of the mechanical part allows reductions in size and mass of the nacelle (Treehugger, 2011).

The substructure connects the transition piece or tower to the foundation at seabed level. In Figure 1(a), a monopile is shown as the foundation system, although other foundation types, discussed later in the paper, may also be used. Together the tower, substructure/support structure and foundation maintain the turbine in its correct operational position. The transition piece provides a means of correcting for any vertical misalignment of the foundation that may have occurred during its installation. In some cases, the foundation can extend to above the water surface, thereby also serving as a substructure by connecting directly to the transition piece or tower.

Figure 2 shows the steady increase in rotor diameter and rated power capacity (RPC) of wind turbines installed over the past 
Energy

Volume 166 Issue EN4

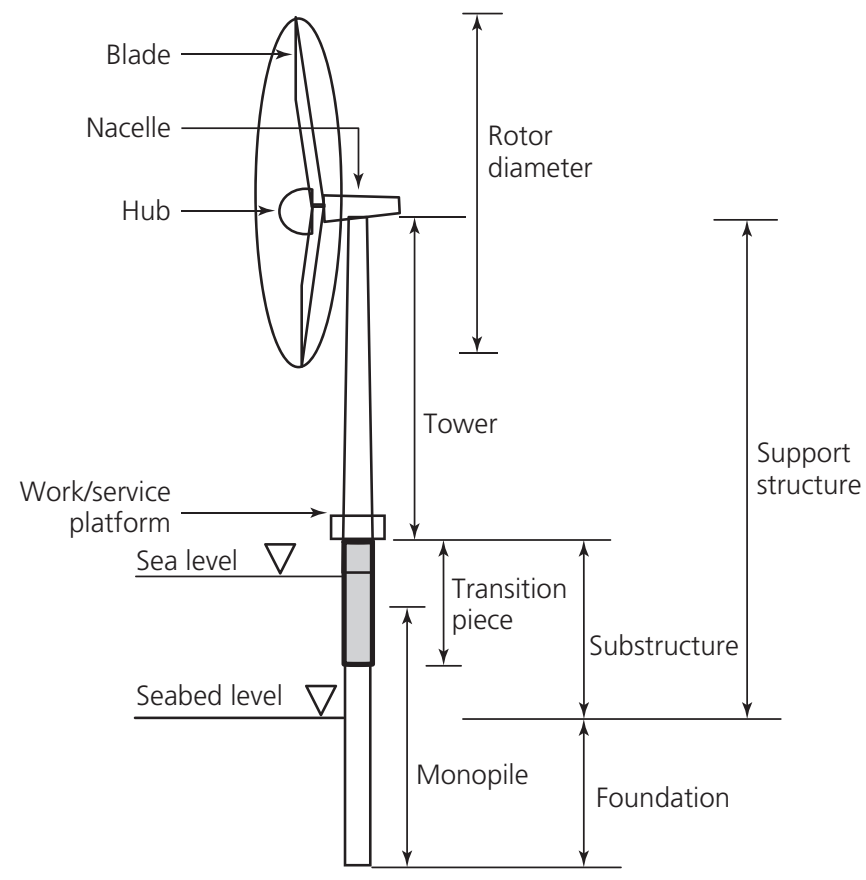

(a)

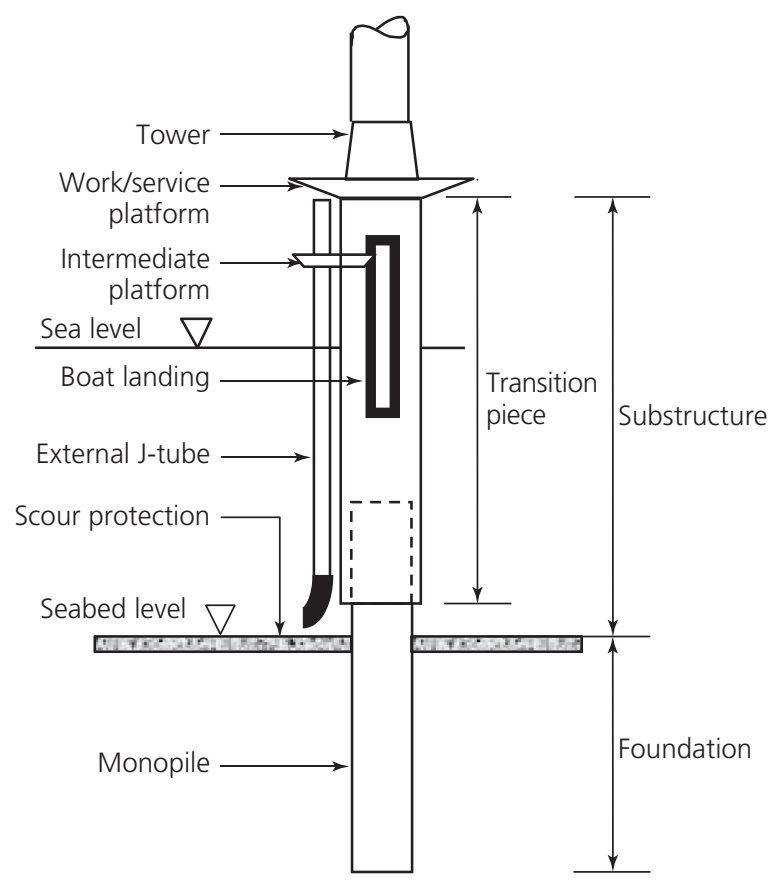

(c)
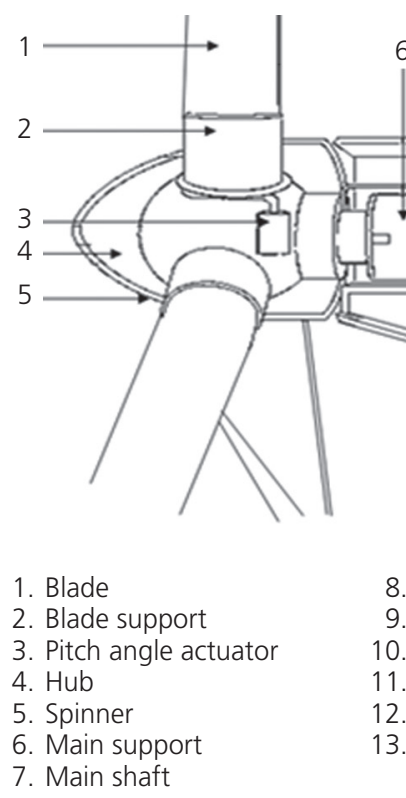
8. Aircraft warning lights
9. Gearbox
10. Mechanical brakes
11. Hydraulic cooling devices
12. Generator
13. Power converter and electrical control, protection and disconnection devices

(b)

Figure 1. Major components of OWT system: (a) wind-turbine system; (b) electromechanical parts adapted from ABB (2012); (c) details of monopile and transition piece

three decades. In particular, between 1990 and 2010, the RPC increased from typically 0.5 to $7.5 \mathrm{MW}$ and rotor diameter from approximately 40 to $150 \mathrm{~m}$ (EWEA, 2011b). Offshore wind turbines having $250 \mathrm{~m}$ rotor diameters and with $\mathrm{RPC} \geq 20 \mathrm{MW}$ are currently in the research and development phase (EWEA, 2011b). Table 1 presents correlations determined from data of more than 150 modern, utility-scale wind turbines which can be used to approximate the size and mass of different OWT components, considering RPC as a key driving input. 


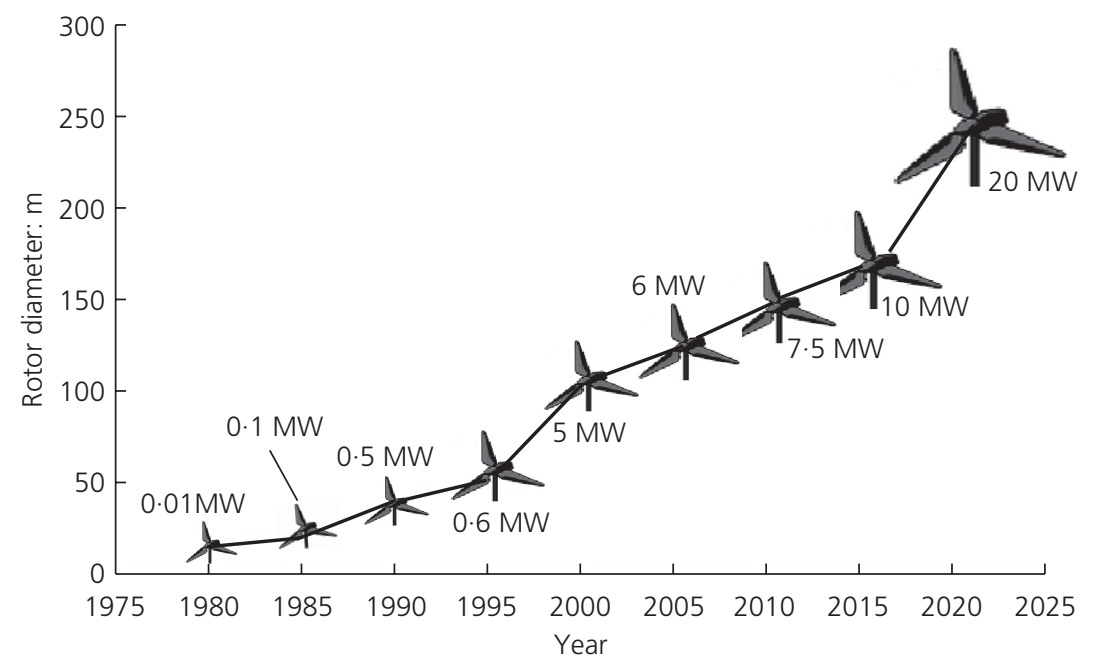

Figure 2. Increase in rotor diameter and RPC of wind turbines

\section{Cost analysis of wind-power generation}

Approximately $70-75 \%$ of the total cost of offshore wind-power production is related to initial capital investment costs, including that of the turbine, foundation, electrical equipment and grid connection (Kooijman et al., 2001; Søren et al., 2009). The 'levelised cost of energy' (LCOE) is the primary measure for quantifying and comparing underlying economics of power projects (Fischer, 2011). For wind-power systems, LCOE represents the sum of all costs, including capital cost, operation and maintenance costs, and also expected annual energy production (Cambell, 2008; Søren et al., 2009) for a fully operational wind-power system over the project's lifetime, with financial flows discounted to a common year. However, empirical methods that use the more extensive databases currently available for onshore wind-power projects in estimating the LCOE for new offshore projects are not reliable (IRENA, 2012).
Between $40 \%$ and $70 \%$ of costs for conventional fossil-fuel-fired technologies are related to fuel, operation and maintenance (Søren et al., 2009). Hence, since fuel costs have no impact on wind-power generation costs, wind turbines are more capital intensive compared with fossil-fuel-fired technologies. In China for instance, the LCOE for onshore wind was almost 300\% and $200 \%$ more costly compared with electric power generation from natural gas and coal, respectively (YFH, 2011), although such cost comparisons are somewhat dependent on the accuracy of projected trends for the costs of fuel, other commodities and logistic facilities. Initial capital investment costs for offshore are approximately double (YFH, 2011) and may reach up to three times that for onshore wind-power projects having similar power generation capacity on account of increased investment required in transportation of materials and turbines, construction and installation of foundations, equipment and turbines at sea
Parameters

Rotor diameter $(D$, in $\mathrm{m})$ and RPC (MW)

Rotor speed ( $R_{\text {speed, }}$ in rpm) and RPC (MW)

Hub height $(\mathrm{HH})$ and rotor diameter $(D)$

Hub mass including pitch, bearing and driver system $\left(M_{(\mathrm{pb}+\mathrm{ds})}\right.$, in t) and RPC (MW)

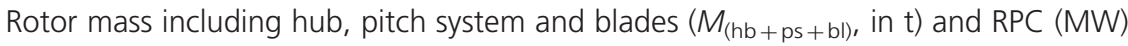

Mass of main rotor shaft $\left(M_{(\mathrm{ms})}\right.$, in $\left.\mathrm{t}\right)$ and RPC (MW)

Mass of main bearing $\left(M_{(\mathrm{mb})}\right.$, in t) and RPC (MW)

Mass of rotor, drive-train support structure and nacelle $\left(M_{(r+d+n)}\right.$, in t) and RPC (MW)

Mass of all components at top of tower $\left(M_{(\text {thm })}\right.$, in t) and RPC (MW)

Table 1. Effect of RPC on size and mass of wind-turbine components (Tong, 2010)

\section{Correlation}

$$
\begin{aligned}
& D=59.354(\mathrm{RPC})^{0.47} \\
& R_{\text {speed }}=22 \cdot 781(\mathrm{RPC})^{-0.3595} \\
& \mathrm{HH}=D / 0.255(D)^{0.3464} \\
& M_{(\mathrm{pb}+\mathrm{ds})}=8.6421(\mathrm{RPC})^{1.1194} \\
& M_{(\mathrm{hb}+\mathrm{ps}+\mathrm{bl})}=18.453(\mathrm{RPC})^{1.1357} \\
& \left(M_{(\mathrm{ms})}\right)=0.2415(\mathrm{RPC})^{2}+3.0699(\mathrm{RPC}) \\
& M_{(\mathrm{mb})}=0.1246(\mathrm{RPC})^{2}+1.2623(\mathrm{RPC}) \\
& M_{(\mathrm{r}+\mathrm{d}+\mathrm{n})}=37.45(\mathrm{RPC})^{0.984} \\
& M_{(\mathrm{thm})}=55.9216(\mathrm{RPC})^{1.0341}
\end{aligned}
$$


Energy

Volume 166 Issue EN4
Offshore wind-turbine structures:

a review

Arshad and O'Kelly and laying offshore cables (IRENA, 2012; Martin et al., 2004). The trend for OWT installations at increasing distances offshore and hence location in greater water depths constitutes a significant factor in the cost analysis for offshore projects. Cost comparisons between onshore and offshore wind-power technologies should be based on evaluations for a specific region and/or country (EEA, 2009). Table 2 shows comparisons between costs for different components of onshore and offshore wind-energy projects.

For wind-power generation, the overall contribution of operation and maintenance $(\mathrm{O} \& \mathrm{M})$ costs to the LCOE is significant and also site specific. Data from different countries including the USA, China and many European countries indicate that O\&M costs for onshore wind power account for between $11 \%$ and $30 \%$ of the total LCOE (IRENA, 2012). The lowest contribution of US $\$ 0 \cdot 010 / \mathrm{kW}$ was reported for the USA, with approximately US\$0.013-0.015/kW reported for best practice in Europe (IRENA, 2012). However, O\&M costs for offshore are significantly greater on account of higher costs incurred in accessing and maintaining the wind turbines, towers and cabling. In the UK, for example, Feng et al. (2010) reported O\&M costs for offshore wind-power projects in shallow water depth were approximately 1.5 times that for onshore projects. Offshore maintenance costs are also higher on account of the harsher marine environment and higher expected failure rates for some electrical and mechanical components. In general, O\&M costs for offshore wind power are typically in the range US\$0.027-0.054/ $\mathrm{kWh}$ (ECN, 2011b). Many existing offshore wind farms are only at the beginning or early stage of their deployment phase. Since data on their O\&M costs remain highly project specific, it will be some time before observable trends emerge and means of reducing these costs are identified. Offshore maintenance facilities may also be necessary to ensure smooth operation of the next generation of OWTs to be installed at greater distances from the shore line. Hence it is clear that the reduction of O\&M costs for offshore wind farms is a key challenge, and once addressed, may improve the economics of offshore wind energy (DouglasWestwood Limited, 2002; IRENA, 2012).

In Europe, LCOE estimates of between $0 \cdot 10$ and $0 \cdot 13 \mathrm{US} \$ / \mathrm{kWh}$ were reported by IEA (2009) for onshore wind in 2011, assuming a typical capacity factor (ratio of average power delivered to theoretical maximum power) for new onshore projects of between $25 \%$ and $30 \%$. For a given capacity factor, assumed cost reductions achievable by 2015 may allow reductions in LCOE of between $6 \%$ and $7 \%$. In North America, the LCOE for onshore wind having a capacity factor of $30 \%$ was estimated at between $0 \cdot 10$ and $0 \cdot 11 \mathrm{US} \$ / \mathrm{kWh}$ for 2011. By 2015, anticipated cost reductions for a given capacity factor may allow reductions in LCOE of between $5 \%$ and $9 \%$ (Wiser and Bolinger, 2011). Compared with Europe and North America, LCOE estimates for onshore wind power in China and India were significantly lower at between 0.07 and $0.08 \mathrm{US} \$ / \mathrm{kWh}$ (2011 data) for a capacity factor of $25 \%$. However, since China and India already have very competitive installation costs for wind-power projects compared to the norm in other developed countries, opportunities for further cost reductions are comparatively smaller. By 2015 , average installation costs may also increase somewhat on account of projected increases in engineering project costs, manufacturing costs for wind turbines in emerging economies and/or the supply situation becoming tighter (E.ON Climate \& Renewables, 2011).

As a general trend, the LCOE for offshore wind-power generation around the globe is typically almost double that of

\begin{tabular}{|c|c|c|}
\hline Item & Offshore & Onshore \\
\hline Initial capital investment cost: US\$/kW & $3300-5000$ & $1700-2450$ \\
\hline $\begin{array}{l}\text { Wind-turbine cost, including production, transportation and installation: \% of initial capital investment } \\
\text { cost }\end{array}$ & $30-50$ & 65-84 \\
\hline $\begin{array}{l}\text { Cost of grid connection including cabling, substations and buildings: \% of initial capital investment } \\
\text { cost }\end{array}$ & $15-30$ & $9-14$ \\
\hline $\begin{array}{l}\text { Construction cost including foundation, transportation and installation of tower and turbine and other } \\
\text { infrastructure (e.g. access roads for onshore) necessary for turbine installation: \% of initial capital } \\
\text { investment cost }\end{array}$ & $15-25$ & $4-16$ \\
\hline Other capital costs including development and engineering costs, licensing procedures, consultancy, & $8-30$ & $4-10$ \\
\hline
\end{tabular}
permits, supervision, control and data acquisition, monitoring systems: \% of initial capital investment cost

Table 2. Cost comparisons for offshore and onshore wind projects

(Douglas-Westwood Limited, 2002; Henderson et al., 2003;

IRENA, 2012; Junginger et al., 2004; Kooijman et al., 2001) 
onshore having similar capacity factors (Roddy et al., 2009). For instance, reported ratios of LCOE for offshore to onshore wind-power projects were 1.3 for Denmark and 1.46 for the UK (Feng et al., 2010; Krohn et al., 2009). Between 2009 and 2011, the overall trend in the LCOE for offshore wind power continued to increase gradually, compared with onshore, which typically showed a small reduction (BNEF, 2011). Hence the LCOE for offshore wind power is likely to remain greater than for onshore (even taking into account higher capacity factors achievable offshore) and will probably remain so, given the significant challenges involved in reducing capital and O\&M costs (Tricklebank, 2008). The main reason for this is the trend of increasing distance offshore (and hence greater water depth) necessary for the next generation of offshore wind-farm operations, which leads to increased costs in all aspects of the supply chain. Turbine prices are increasing due to necessary design improvements to achieve greater reliability in the harsh marine environment and also on account of larger, more sophisticated wind turbines necessary to increase capacity factors (Maria, 2009). Construction and cabling costs also increase as a function of water depth/distance offshore. However, encouragingly, a recent study performed in China (IEA, 2011) indicated that by 2020, 2030 and 2050, initial capital investment costs for offshore wind-power projects located in up to $50 \mathrm{~m}$ water depth are estimated to reduce by $25 \%, 36 \%$ and $50 \%$, respectively, compared with current initial capital investment costs (2010 data). Furthermore a $33 \%$ reduction in O\&M costs was predicted by 2030 , although no further reduction was anticipated between 2030 and 2050. In Europe, respective reductions of $15 \%$ and $20 \%$ in initial capital investment and O\&M costs are estimated to occur between 2006 and 2015, although further reductions of approximately $10 \%$ in initial capital investment costs are expected for offshore windpower projects between 2020 and 2050 (CEC, 2007; Søren et al., 2009).

\section{Foundation systems}

Support structures/foundations for offshore wind farms are generally more complex than for onshore, involving greater technical challenges, including design requirements to withstand the harsh marine environment and prolonged impact under large wave loading (see Figure 3). The various support structure/foundation concepts employed (Figure 4), which have been adopted from the offshore oil and gas industry, are usually categorised as either bottom-mounted structures (i.e. rigidly connected to the seabed through a foundation system) or floating-support structures that have no rigid connection with the seabed. The foundation solution adopted depends on local seabed conditions, water depth and financial constraints (AWS True wind, 2010; Igoe et al., 2013).

At present, monopiles (Figures 4(b) and 4(c)) are by far the most widely adopted substructure-foundation system for modern

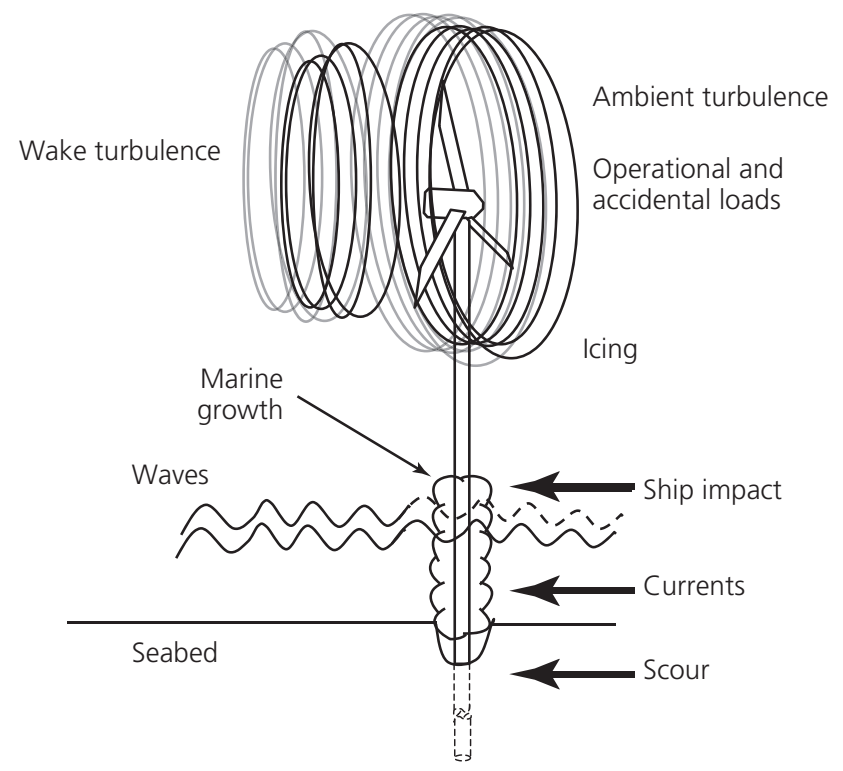

Figure 3. Environmental impacts on OWTs

offshore wind farms located in shallow water depths $(\leq \sim 40 \mathrm{~m})$. Such monopiles consist of a steel tubular section (pipe pile), typically 4-6 $\mathrm{m}$ in diameter and up to $1000 \mathrm{t}$ in mass, which transfers the applied vertical and larger lateral loading into the seabed foundation. Its complete installation is usually achieved within $24 \mathrm{~h}$ (Fischer, 2011; Junginger et al., 2004; Saleem, 2011). Cyclic lateral and moment loading on the monopile are resisted by horizontal earth pressures mobilised in the surrounding soil along the monopile embedded length. The monopile embedment length is dependent on seabed characteristics/properties and total applied load. An embedment length of $30 \mathrm{~m}$ is usually deemed sufficient to meet design criteria, including vertical stability and horizontal deflection requirements (Musial and Bonnie, 2010; Tricklebank, 2008).

Braced support structures (i.e. tripod and jacket/truss) are more suitable for deeper water and heavier turbines (Esteban et al., 2011; Fischer, 2011). Tripods consist of a large-diameter central steel tubular section that is supported over its lower length by three braces (Figure 4(d)), which are connected to the seabed. A range of different foundations can be employed including gravity bases, suction buckets or piles. In this manner, the structural and environmental loads applied on the OWT and the supporting structure are mostly transferred axially through the braces to the seabed foundation. Complete installation of a tripod foundation system with, for example, a water surface to seabed length of up to $50 \mathrm{~m}$ and mass of up to $700 \mathrm{t}$, typically takes between two and three working days, often requiring special equipment for driving/drilling and working under water (Esteban et al., 2011; Fischer, 2011). A jacket/braced frame structure (Figure 4(e)) is a lattice frame 
Energy

Volume 166 Issue EN4

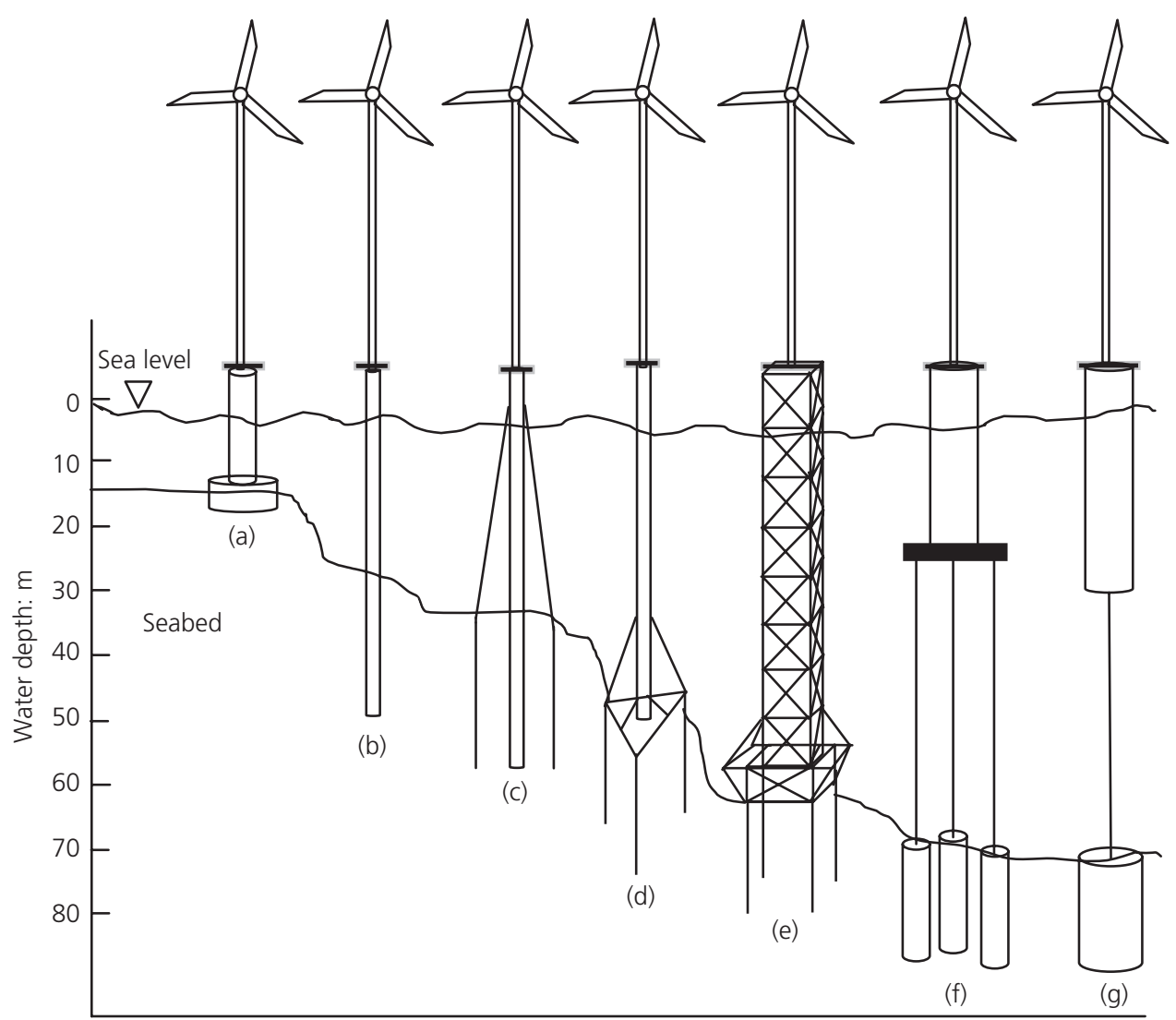

Figure 4. Support structure/foundation options for OWTs:

(a) gravity; (b) monopile; (c) monopile with guy wire; (d) tripod;

(e) braced frame; ( $f$ ) tension leg with suction buckets (ballast stabilised);

(g) buoy with suction anchor

of small-diameter steel struts that (similar to tripods) is anchored to the seabed using one of the different foundation options. Complete installation generally takes up to 3 days. Braced frame structures are particularly suitable for severe maritime weather since the strut components offer lower resistance to prevailing ocean wave and current flow in comparison with monopile or tripod structures. Braced frame structures are also more adaptable to conditions encountered on site, increasing their application range, with geometrical variations of the substructure achieved relatively simply but without altering the stiffness of the whole structure (Vries, 2007).

In the future, it is anticipated that floating structures, which are currently only at research and development stage, will be commercially used, particularly for water depths greater than $50 \mathrm{~m}$ (Saleem, 2011). Such floating platforms for wind turbines will impose many new design challenges. Currently, tension-leg platform concepts (see Figure 4(f)) are considered as most economical (Fischer, 2011) because rigid body modes of the floater are limited to horizontal translation (surge and sway) and rotation around the vertical axis (yaw). Other examples include spar-floater and barrage-floater systems. For the sparfloater (Figure 4(g)), buoyancy is provided to the wind-turbine structure by a long, slender cylinder/capsule that protrudes below the water line (Esteban et al., 2011; Fischer, 2011; Vries, 2007). For the barrage floater, the wind-turbine structure is placed on a barrage and attached by way of anchor lines to the seabed.

From the various foundation systems described above, monopiles are currently by far the most popular solution used worldwide, with $75 \%$ share, in comparison with only $5 \%$ for jacket/tripod options (E.ON Climate \& Renewables, 2011). However, it is estimated that by 2020 , between $50 \%$ and $60 \%$ of new OWTs will be supported by monopiles and a further $35-40 \%$ by jacket/tripod systems (Babcock and Brown Company, 2012). The main reason for this shift is the attraction of jacket/tripod systems for deeper sea locations, which provide consistently higher wind speeds and hence greater wind energy (Tempel and Molenaar, 2002). 


\section{Comparison of environmental loading for offshore and onshore wind-turbine structures}

Offshore wind-turbine structures are designed to resist loading from hydrodynamic, aerodynamic and also ice and ship-impact sources, whereas onshore structures are principally designed to withstand aerodynamic loading. Aerodynamic loading results from interactions of the rotor and parts of the tower within the turbulent air field, with the generated wind power directly proportional to the cube value of mean wind speed. Aerodynamic conditions for offshore and onshore scenarios are markedly different, with considerably lower fluctuation in loading experienced for offshore on account of associated free-flow conditions and lower surface roughness, although advantages of reduced dynamic loading are partly undone by higher mean wind speeds (Fischer, 2011; Tricklebank, 2008). In general, aerodynamic loading can be characterised by (DNV, 2011)

- vertical wind profile

- mean wind-speed distribution

- turbulence effects.

For offshore, surface roughness is low, increasing only marginally in the event of severe sea states with high waves. Hence wind speed increases sharply with increasing elevation above sea level, producing very steep wind-speed profiles compared with onshore sites. The mean value of $10 \mathrm{~min}$ wind-speed data (either measured at a reference elevation of $10 \mathrm{~m}$ above mean sea level or usually determined at hub height for OWTs) is referred to as wind speed $\bar{U}_{10}$. The mean wind speed $\bar{U}_{z}$ at some other elevation $z$ above mean sea level can be approximated by

$$
\text { 1. } \bar{U}_{z}=\bar{U}_{10}\left(\frac{z}{10}\right)^{\alpha}
$$

where values of $\alpha$ range between 0.11 and 0.40 depending on site location; for example, $\alpha=0 \cdot 11$ for open sea conditions, $0 \cdot 16$ for grassland and 0.40 for city centre/urban environments (Haritos, 2007; Journée and Massie, 2001).

For offshore sites, steep profiles of wind speed for the vertical direction usually necessitate lower hub heights, with minima values generally dictated by clearance limits to the turbine's service platform (see Figure 1(a)). Periodic loading effects are also reduced since the difference in mean wind speed between upward and downward moving blades is low (Fischer, 2011). In contrast, the gain in wind energy with increasing hub height is the driver for onshore design. Wind-speed distribution, which also differs between onshore and offshore, is generally described by a Weibull distribution function (DNV, 2011) that quantifies the probability of different mean wind speeds occurring over a given time period at the site location. The probability density function $\left(f_{\text {wind }}\right)$ of a Weibull random variable $v$ is given by

$$
\text { 2. } f_{\text {wind }}=\frac{k}{A}\left(\frac{\nu}{A}\right)^{k-1} \exp \left[-\left(\frac{\nu}{A}\right)^{k}\right]
$$

where $A$ is a scalar and $k$ is a shape factor that quantifies the width of the wind-speed distribution.

The values of $A$ and $k$ are larger for offshore, indicating higher probability of greater wind speeds compared with onshore (Fischer, 2011; Tricklebank, 2008). Greater differences in wind-speed distributions over time for offshore compared with onshore produce higher levels of mean wind load and hence greater power output. Long-term variations in wind speed are significant in terms of predicting energy yield from a wind turbine, whereas short-term fluctuations are more relevant for generated wind loads. The degree of turbulence (defined as momentary deviations from the mean wind speed) depends on meteorological and geographical conditions, for example, atmospheric layering and terrain. The main contributors to extreme loading and fatigue are stochastic effects in shortterm fluctuations of wind speed, such as turbulence/transient events such as gusts (Quarton et al., 1996). A measure for turbulence is turbulence intensity: the ratio of the standard deviation of wind speed to mean wind speed for a given time period (DNV, 2011). For a particular site, turbulence intensity correlates with wind speed and surface roughness; higher wind speed and lower surface roughness produce lower turbulence (Vries, 2007). Since wind is the primary energy source for ocean waves, higher wind speed may produce marginal increases in turbulence on account of ensuing increases in roughness of the ocean surface (Letchford and Zachry, 2009). Another aspect of fluctuating wind speed is turbulence induced in wake conditions (see Figure 3). Ambient nonobstructed turbulence is the 'normal' turbulence experienced by a single stand-alone turbine at a particular site (Frandsen and Thøgersen, 1999). Wake effects can be significant, especially for dense wind-park layouts, where neighbouring turbines experience a superimposed turbulent wind coming from the ambient and wake.

Since surface roughness and hence ambient turbulence are lower for offshore sites, the combination of ambient and wakeinduced turbulence is also comparatively lower although wake fields remain longer in the atmosphere compared with onshore. The frequency of energy-rich wind turbulence is below $0.1 \mathrm{~Hz}$ (LeBlance, 2009). Hence, turbulence is not significant in the determination of the structural design loads for extreme levels of environmental loading, although its effect on fatigue life of wind-turbine structures cannot be ignored (Vries, 2007). Offshore wind turbines are generally designed for more severe wind classes since the probability of 
Energy

Volume 166 Issue EN4
Offshore wind-turbine structures:

a review

Arshad and O'Kelly extreme wind speeds (e.g. due to gusts or changes in wind direction) is more significant compared with most onshore sites (GL, 2005).

Compared with the rotor thrust reaction to wind loads, the hydrodynamic forces acting on OWTs generally only have a minor role in the development of tower deflection. LeBlance (2009) reported that this was largely due to the reduced wave-interaction area of the substructure as compared with the overall tower length and greater lever arm of the rotor thrust (see Figure 1(a)). However, the density of the medium must also be considered when comparing aerodynamic and hydrodynamic lateral loading, with the density of sea water significantly greater than that for air. Hydrodynamic forces generally only become significant for greater water depths and/or wave heights, which cause the lever arm of the hydrodynamic force to increase along with the intensity of the lateral force generated by the water (Fischer, 2011). The height of the ocean waves is usually expressed in terms of 'significant wave height'; this is defined as the mean value of the highest one-third of the waves in a given wave record. Ocean waves that induce fatigue loading with high frequency usually have significant wave heights of $\sim 1.0-1.5 \mathrm{~m}$ and a zero-crossing period of 4-5 s (Vries, 2011).

\section{Loading frequency, natural vibration frequency and resonance}

It is essential to consider the fundamental natural frequency of a wind-turbine structure for a proper description and evaluation of its dynamic behaviour. As for all dynamic systems, resonance occurs when an excitation frequency gets close to the structure's fundamental natural frequency. For wind-turbine structures,

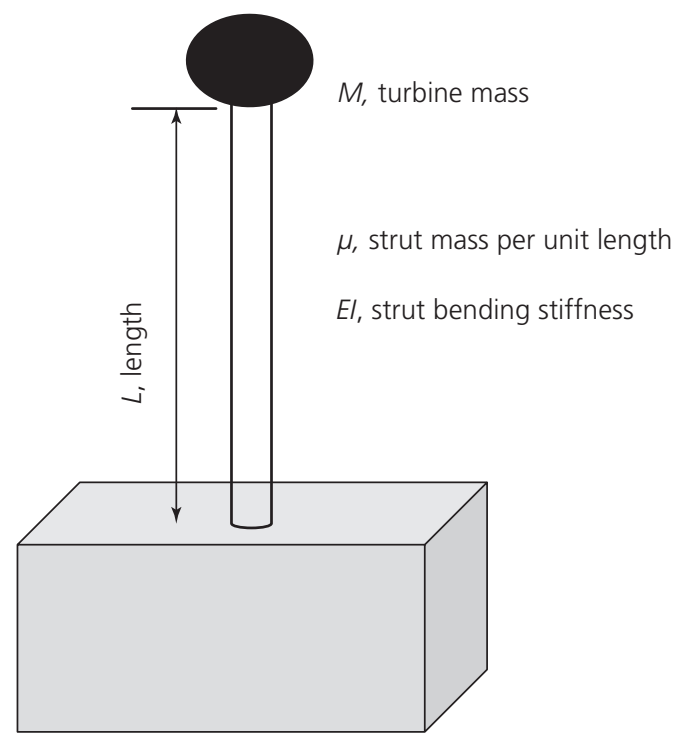

Figure 5. Structural model for flexible wind-turbine system this invariably leads to the development of higher stresses in the support structure and foundation, but more significantly to a higher range of stresses - an unfavourable situation in considering fatigue life. Hence it is important to ensure that excitation frequencies having high energy levels do not coincide with the support structure's fundamental natural frequency. As a first approximation, the support structure's fundamental natural frequency can be determined by considering a simplified geometry for the whole structure (Figure 5). The turbine mass $(M)$ is concentrated at the top (free end) of an equivalent steel pipe representing the support structure, with similarities to a cantilevered vertical strut. In this instance, the first natural frequency $\left(f_{\text {nat }}\right.$, in $\mathrm{Hz}$ ) of the combined structure can be approximated by (Tempel, 2006)

$$
\text { 3. } f_{\text {nat }}^{2}=\frac{3 \cdot 04}{4(\pi)^{2}} \frac{E I}{(0 \cdot 227 \mu L+M) L^{3}}
$$

where $\mu$ is the strut mass per unit length, $L$ is the strut length and $E I$ is its bending stiffness $\left(\mathrm{N} \mathrm{m}^{2}\right)$.

Offshore wind-turbine structures are excited by both wind and waves, with the effective wind load determined by complex interactions between the structural dynamics of the turbine and wind field. Site-specific spectral densities for wind and waves can be derived either from data measured for the particular site location, from met-ocean databases or numerical models (LeBlance, 2009).

Dynamic amplification and large excitation forces affect monopiles in a cumulative unfavourable manner. With rotational speeds of the main rotor shaft typically between 10 and $20 \mathrm{rpm}$, the first excitation frequency ' $1 \mathrm{P}$ ' (i.e. corresponding to one full revolution) occurs in the range $0 \cdot 17-0.33 \mathrm{~Hz}$. In general, only light excitation of the $1 \mathrm{P}$ frequency should occur, with large excitations arising on account of excessive mass and/or aerodynamic imbalances. For a three-bladed turbine, the blade passing frequency of typically $0.5-1.0 \mathrm{~Hz}$ is

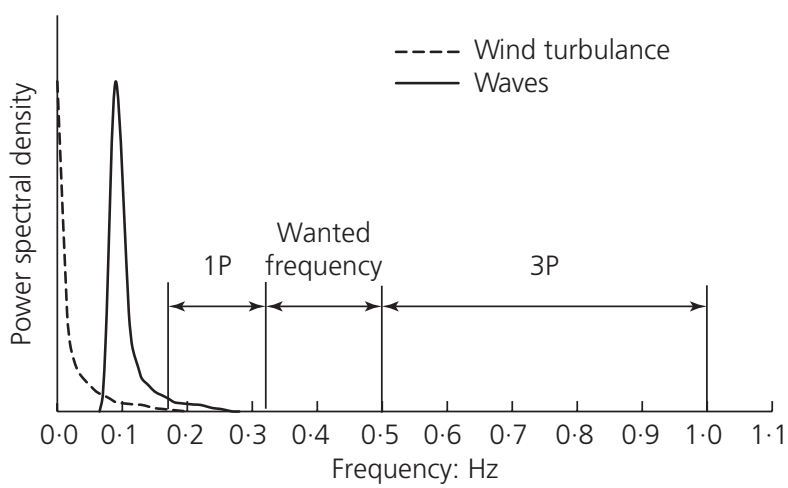

Figure 6. Excitation ranges for OWT structures 
denoted as the ' $3 \mathrm{P}$ ' frequency and is heavily excited on account of impulse-like excitation arising from the individual blades passing by the tower.

Figure 6 shows the excitation ranges of $1 \mathrm{P}$ and 3P, along with realistic, normalised power spectra for wind and wave excitations. Referring to the figure, the 'soft-stiff' zone includes the $1 \mathrm{P}, 3 \mathrm{P}$ and 'wanted frequency' regions; the region before the $1 \mathrm{P}$ range is referred to as the 'soft-soft' zone and the region after the 3P range as 'stiff-stiff'. 'Soft-soft' and 'stiffstiff ' zones are unsuitable for the design solution. The structure is considered too flexible if its fundamental natural frequency falls within the 'soft-soft' zone and too rigid (heavy and expensive) within the 'stiff-stiff' zone. Another important reason for avoiding the 'soft-soft' frequency region is that wave- and wind-turbulence excitation frequencies usually fall within this zone (LeBlance, 2009); see Figure 6.

Excitation/resonance of a dynamic system can be mitigated by damping, achieved either internally by friction in components of the structural system or externally by some source/force. Overall damping of an offshore structure can be achieved by combinations of aerodynamic, hydrodynamic, structural and/ or soil damping (refer to Bittkau (2010), Genta (1998) and Rodenhausen (2010) for further details).

For the popular monopile foundation systems, 'soft-stiff' design necessitates relatively high structural and dynamic stiffness, which can be achieved by increasing the monopile diameter, or less efficiently, by increasing (reinforcing) the pile wall thickness. However, larger diameter monopiles introduce drawbacks, including greater wave loading and also larger driving equipment/forces necessary for installation (Schaumann and Böker, 2005). Hence there is a corresponding increase in the initial capital investment costs of the project, although from the authors' perspective the LCOE may not be adversely affected if rated power capacity is also increased by using larger rotor blades. Compared with monopiles, the lattice frame of jacket/truss support structures (Figure 4(e)) provides large structural bending stiffness and more favourable mass-to-stiffness ratio, resulting in relatively high bending Eigen-frequencies and reduced hydrodynamic excitation (Vries, 2011), although torsional stiffness is reduced, potentially leading to dynamic problems. Jacket support structures are designed for operation in or around 'stiff-stiff' regions (Fischer, 2011). In the case of tripods, bracing along the lower length of the central tubular section increases overall bending stiffness and reduces bending moment loading on the foundation (Saleem, 2011; Schaumann and Böker, 2005), with typical Eigen-frequencies ranging between those for monopile (at lower end of this range) and jacket support structures/ foundations under similar rotor-nacelle configurations and environmental conditions.

\section{Challenges for offshore wind-power generation}

Offshore wind-power generation has arguably greater potential compared with onshore, but marine conditions pose great challenges to project delivery because outcomes are highly influenced by environmental conditions. Some outlooks and new approaches to offshore windpower are discussed below.

\subsection{Implementation, fabrication, operation and maintenance}

It could be argued that, owing to the involvement of multiple regulatory and planning bodies, the current planning and implementation process for offshore wind-power farms is too complex and time-consuming. Some primary legislation may be helpful in order to facilitate relevant government bodies working amicably with investors and developers for offshore wind-power farms (CT, 2008).

Fabrication and O\&M issues place major pressures on the LCOE for offshore wind farms (ABB, 2012; IRENA, 2012). New offshore strategies must be developed to minimise the number of tasks performed at offshore sites. Materials for wind-turbine fabrication must be selected for durability and environmental tolerance. Engineering design, beginning from preliminary concepts, must rigorously place higher premiums on reliability, float-out deployments and in situ repair methods. Fabrication facilities must be strategically located for mass production, onshore assembly and rapid deployment offshore, with minimal dependence on large vessels (EWEA, 2007). Sensitive electronic devices for remotely sensing weather conditions and self-diagnostic systems to manage O\&M of electromechanical components are required in order to minimise downtime and reduce equipment necessary for repairs (CleanTech, 2012). Ultimately a new balance between initial capital investment costs and long-term operating costs needs to be established that will have a broad impact on the LCOE for offshore wind technology.

\subsection{Offshore design codes and methods}

One of the immediate challenges for design is the ability to accurately predict the magnitude and distribution of applied environmental loads and the resulting dynamic response of the coupled wind-turbine and support structure under the action of combined stochastic wave and wind loading (Musial and Butterfield, 2006). At present, analysis, design and installation of monopile foundations for wind-turbine structures usually rely on general geotechnical standards, complemented by more specific guidelines and semi-empirical formulas developed by the offshore oil and gas industry (API, 2007; DIN, 2005; DNV, 2011; GL, 2005).

However, large-diameter monopile foundations for proposed offshore wind-turbine structures are well outside the scope of current experience and analysis/design methods (including the 
American Petroleum Institute (API, 2007) and Det NorskeVeritas (DNV, 2011) standards used by the offshore oil and gas industry). These standards are largely based on empirical data obtained for relatively small-diameter flexible piles under low numbers of load cycles. Furthermore, for these standards, wave loading is of primary concern when extrapolating to predict extreme events. However, designers of offshore windturbine structures must consider wave and wind load spectra simultaneously (IEC, 2005; Tarp-Johansen, 2005). Hence careful consideration of these differences in applied loading and inherent limitations underpinning semi-empirical formulae for the offshore oil/gas industry are required in extrapolation for design of large-diameter monopile foundation supports for wind-turbine structures. Often these formulations cannot be applied with confidence by the offshore wind-power industry to achieve optimum results and economy (Dobry et al., 1982).

There is also a dearth of knowledge concerning the behaviour of the monopile-soil foundation system and its structural stability under long-term cyclic lateral loading. Existing literature includes Matlock (1970), Reese et al. (1974, 1975), Little and Briaud (1988), Ismael (1990) and Long and Vanneste (1994). Hence the development of more realistic strain-accumulation models and also computer codes to predict dynamic forces and resulting displacements of OWTs will provide valuable tools for more reliable designs.

\subsection{Recommendations for future research and practice} A multidisciplinary approach is suggested in order to strive towards making the offshore wind-power industry more economical and practicable, including the following points.

- Some primary legislation may be helpful in order to facilitate relevant government bodies in working amicably with investors and developers for offshore wind-power farms. Investors and developers for offshore-wind projects could be facilitated by government with some easing of current requirements to obtain obligation certificates.

- Development of innovative fabrication materials (with appropriate strength, durability and lightweight characteristics) for OWTs may contribute to considerable reductions in the LCOE.

- Use of more sophisticated electromechanical parts in OWTs (e.g. direct-drive units that eliminate the requirement for a gearbox, thereby removing one of the key components prone to failure) will increase the efficiency and hence energy yield and also reduce O\&M costs for the project.

- In-depth experimental and numerical studies are necessary in order to bridge the knowledge gap between existing design codes/guidelines developed for the offshore oil and gas industry and more onerous applied loading and larger support structures/foundations adopted for OWTs.

\section{Summary and conclusions}

Wind power, particularly from offshore turbines mounted on bottom support structures, appears to be a promising solution to meet the universal demand for clean, cost-effective energy. The rated power-generation capacity of individual OWTs, and also of wind farms, has increased many-fold over the past two decades, with strong growth projected to continue for the nearto-medium future. Concepts for floating foundation systems for OWT structures are also emerging, which will allow installations even farther offshore, thereby benefiting from relatively higher wind speeds/power generation. However, compared with conventional fossil-fuel-fired technologies, initial capital investment costs and LCOE for wind-power generation are both comparatively higher, particularly for offshore, on account of challenges associated with the harsh marine environment. Reductions in the LCOE and projected increases in design life of OWT projects are achievable by developing and implementing improved design criteria/methods for foundations, support structures and the wind turbines themselves, along with the use of innovative materials in their fabrication.

The wind-power generation industry can be facilitated through legislation leading to primary reforms in the rules/regulations imposed by different regulatory and monitoring bodies related to this industry. A multidisciplinary and integrated approach is required, with cost reductions achievable for other offshore industries (e.g. oil/gas sector and offshore cable laying) potentially also benefiting offshore wind-power projects, although developments in commodity prices (particularly steel, copper, cement) will also influence potential cost reductions achievable for wind power. In spite of such challenges, it is projected that wind-power generation will continue to increase many-fold, particularly in Europe, North America and Asia over the next two decades, with associated LCOE anticipated to become comparable with other sources of renewable energy.

\section{Acknowledgements}

The first author gratefully acknowledges a postgraduate research award from Trinity College Dublin.

\section{REFERENCES}

ABB (2012) Wind Power Plants. Technical Application Paper

No. 13. See http://www05.abb.com/global/scot/scot209.nsf/ veritydisplay/92faf0c1913f5651c1257937002f88e8/\$file/

1sdc007112g0201.pdf (accessed 10/10/2012).

Alderlieste EA (2010) Experimental Modelling of Lateral Loads on Large Diameter Mono-pile Foundations in Sand.

MSc thesis, Delft University of Technology, the Netherlands.

API (American Petroleum Institute) (2007) API RPA2:

Recommended practice for planning, designing and constructing fixed offshore platforms - working stress design, 22nd edn. API, Washington, DC, USA. 
AWEA (American Wind Energy Association) (2012) Facts About Offshore Wind. See http://offshorewindworks.tumblr. com/facts (accessed 18/09/2012).

AWS True wind (2010) New York's Offshore Wind Energy Development Potential in the Great Lakes: Feasibility Study; 2010. See http://www.awstruepower.com/wp content/ media/2010/09/NYSERDA_AWST_NYGreatLakesFS.pdf (accessed 10/07/2012).

Babcock and Brown Company (2012) The Future of Offshore Wind Energy. See http://bluewaterwind.com (accessed 20/08/2012).

Bittkau R (2010) Concept Study for Using Active Turbine Controls vs. Structural Control Systems for Load Mitigation for Offshore Wind Turbines Using Monopile Support Structures. University of Stuttgart, Stuttgart, Germany, Research Report.

BNEF (Bloomberg New Energy Finance) (2011) Levelised Cost of Energy Update, Q2 2011, Research Note. BNEF, London, UK.

Cambell M (2008) The Drivers of the Levelised Cost of Electricity for Utility-scale Photovoltaics. See http://large. stanford.edu/courses/2010/ph240/vasudev1/docs/sunpower. pdf (accessed 15/08/2012).

CEC (Commission of the European Communities) (2007) Renewable Energy Road Map, Renewable Energies in the 21st Century: Building a More Sustainable Future. See http://ec.europa.eu/energy/energy_policy/docrenewable_ energy_roadmap_full_impact_assessment_en.pdf (accessed 10/09/2012).

CleanTech (2012) Offshore Wind: the Technology Challenge. See http://www.cleantechinvestor.com/portal/wind-energy/ 5573-offshore-wind-the-technology-challenge.html (accessed 10/08/2012).

CT (Carbon Trust) (2008) Offshore Wind Power: Big Challenge, Big Opportunity Maximising the Environmental, Economic and Security Benefits. See http://www. carbontrust.com/media/42162/ctc743-offshore-wind-power. pdf (accessed 10/07/2012).

Damien T and Mo M (2002) The Potential for Renewable Energy Usage in Aquaculture. See http://www. aquacultureinitiative.eu/Renewable \%20Energy\%20Report. pdf (accessed 05/08/2012).

DIN (Deutsches Institut für Normung) (2005) Baugrund Sicherheitsnachweise im Erd und Gundbau. DIN, Berlin, Gemerany, DIN 1054: 2005. See http://www. baunormenlexikon.de/Normen/DIN/DIN\%201054/1b69b62174a0-4c33-8b29-a82a24afd4d4 (accessed 15/06/2012).

DNV (Det Norske Veritas) (2011) Design of Offshore Wind Turbine Structures. DNV, Oslo, Norway, DNV-OS-J101.

Dobry R, Vincente E, O'Rourke M and Roesset J (1982) Stiffness and damping of single piles. ASCE Journal of Geotechnical Engineering 108(3): 439-458.

Douglas-Westwood Limited (2002) The World Offshore Renewable Energy Report 2002-2007. See http:// webarchive.nationalarchives.gov.uk/+/http://www.dti.gov. uk/energy/renewables/publications/pdfs/offshorereport.pdf (accessed 05/10/2012).

ECN (Energy Research Centre of the Netherlands) (2011a) Roadmap to the Deployment of Offshore Wind Energy in the Central and Southern North Sea (2020-2030). See http:// www.windspeed.eu/media/publications/WINDSPEED_ Roadmap_110719_final.pdf (accessed 02/03/2013).

ECN (2011b) Properties of the O\&M Cost Estimator. See http:/ www.ecn.nl/docs/library/report/2011/e1 1045.pdf (accessed 04/02/2013).

EEA (Eurpean Environmental Ageny) (2009) Europe's Onshore and Offshore Wind Energy Potential: An Assessment of Environmental and Economic Constraints. See http://www. envirocentre.ie/includes/documents/Europes_onshore_and_ offshore_wind_energy_potential[1].pdf (accessed 20/01/2013).

E.ON Climate \& Renewables (2011) Offshore Wind Energy Fact Book. See http://www.eon-einkauf.com/content/dam/ eoncom/en/downloads/e/EON_Offshore_Wind_Factbook_ en_December_2011.pdf (accessed 16/08/2012).

Esteban M, Lopes-Gutierrez J, Diez J and Negro V (2011) Foundations for offshore wind farms. Proceedings of the 12th International Conference on Environmental Science and Technology, Rhodes, Greece, pp. 516-523.

EWEA (European Wind Energy Association) (2007) Delivering Offshore Wind Power in Europe. See http://www.ewea.org/ fileadmin/ewea_documents/images/publications/ offshorereport/ewea-offshore_report.pdf (accessed 10/10/ 2012).

EWEA (2009) Pure Power Wind Energy Targets for 2020 and 2030. See www.ewea.org/fileadmin/ewea.../Pure_Power_III. pdf (accessed 14/03/2012).

EWEA (2011a) The European Offshore Wind Industry Key Trends and Statistics 2010. See http://www.ewea.org/ fileadmin/files/library/publications/statistics/EWEA_stats_ offshore_2011_02.pdf (accessed 06/08/2012).

EWEA (2011b) Design Limits and Solutions for Very Large Wind Turbines. UpWind Project. See http://www.ewea.org/ fileadmin/ewea_documents/documents/upwind/21895_ UpWind_Report_low_web.pdf (accessed 04/02/2013).

EWEA (2012) The European Offshore Wind Industry Key Trends and Statistics 2011. See http://www.ewea.org/ fileadmin/files/library/publications/statistics/EWEA_stats_ offshore_2011_02.pdf (accessed 06/08/2012).

Feng Y, Tavner PJ and Long H (2010) Early experiences with UK Round 1 offshore wind farms. Proceedings of the Institution of Civil Engineers - Energy 163(4): 167-181.

Fischer T (2011) Executive Summary - UpWind Project. WP4: Offshore Foundations and Support Structures. See http:// www.upwind.eu/pdf/WP4_Executive_Summary_Final.pdf (accessed 12/09/2012).

Frandsen S and Thøgersen M (1999) Integrated fatigue loading for wind turbines in wind farms by combining 
ambient turbulence and wakes. Wind Engineering 23(6): 327-339.

Genta G (1998) Vibration of Structures and Machines, 3rd edn. Springer, New York, NY, USA.

GL (Germanischer Lloyd) (2005) Rules and Guidelines, IV Industrial Services, 2 Guideline for the Certification of Offshore Wind Turbines, 6 Structures. See http://onlinepubs. trb.org/onlinepubs/mb/Offshore\%20Wind/Guideline.pdf (accessed 17/09/2012).

GWEC (Global Wind Energy Council) (2011) Global Wind Report - Annual Market Update. See http://www. windpower-international.com/microsites/gwec/Annual_ report_2011_lowres.pdf (accessed 14/09/2012).

Haritos N (2007) Introduction to the analysis and design of offshore structures - an overview. Electronic Journal of Structural Engineering 7(Special Issue): 55-65.

Henderson A, Morgan C, Smith B et al. (2003) Offshore wind energy in Europe - a review of the state-of-the-art. Wind Energy 6(1): 35-52.

IEA (International Energy Agency) (2009) Annual Report 2008. See http://www.ieawind.org/Annual_reports_PDF/ 2008/2008\%20AR_small.pdf (accessed 10/09/2012).

IEA (2011) China Wind Energy Development Roadmap 2050. See http://www.iea.org/publications/freepublications/ publication/china_wind.pdf (accessed 01/03/2013).

IEC (International Electrotechnical Commission) (2005) IEC 61400-1: Wind turbines - Part 1: Design requirements, 3rd edn. IEC, Geneva, Switzerland.

Igoe D, Gavin K and O'Kelly B (2013) An investigation into the use of push-in pile foundations by the offshore wind sector. International Journal of Environmental Studies, http://dx.doi. org.10.1080/00207233.2013.798496 (accessed 01/10/2013).

IRENA (International Renewable Energy Agency) (2012) Renewable Energy Technologies: Cost Analysis Series, http://www.irena.org/Document.Downloads/Publications/ RE_Technologies_Cost_Analysis-WIND_POWER.pdf (accessed 15/05/2012).

Ismael N (1990) Behaviour of laterally loaded bored piles in cemented sands. ASCE Journal of Geotechnical Engineering 116(11): 1678-1699.

Journée JMJ and Massie WW (2001) Offshore Hydrodynamic, 1st edn. Delft University of Technology, Delft, the Netherlands.

Junginger M, Agterbosch S, Faaij A and Turkenburg W (2004) Renewable electricity in the Netherlands. Energy Policy 32(9): 1053-1073.

Kooijman H, Noord MD, Volkers C et al. (2001) Cost and potential of offshore wind energy on the Dutch part of the North Sea. Proceedings of the European Wind Energy Conference and Exhibition, Copenhagen, Denmark.

Krohn S, Morthrost P and Awerbuch S (eds) (2009) Economics of Wind Energy. European Wind Energy Association, Brussels, Belgium.
LeBlance C (2009) Design of Offshore Wind Turbine Support Structures - Selected Topics in the Field of Geotechnical Engineering. PhD thesis, Aalborg University, Denmark.

Letchford C and Zachry B (2009) On wind, waves, and surface drag. Proceedings of the 5th European and African Conference on Wind Engineering, Florence, Italy, pp. 83-114.

Little RL and Briaud JL (1988) Full Scale Cyclic Lateral Load Tests on Six Single Piles in Sand. Geotechnical Division, Texas A\&M University, College Station, TX, USA, miscellaneous paper GL-88-27.

Long J and Vanneste G (1994) Effects of cyclic lateral loads on piles in sand. ASCE Journal of Geotechnical Engineering 120(1): 225-244.

Malhotra S (2011) Design and construction considerations for offshore wind turbine foundations in North America. In Wind Turbines (Al-Bahadly I (ed.)). InTech, Rijeka, Croatia, pp. 231-264.

Maria IB (2009) The economics of wind energy. Renewable and Sustainable Energy Reviews 13(6-7): 1372-1382.

Martin J, André F and Wim CT (2004) Cost reduction prospects for offshore wind farms. Wind Engineering 28(1): 97-118.

Matlock H (1970) Correlation for design of laterally loaded piles in soft clay. Proceedings of the Offshore Technology Conference, Houston, TX, USA, pp. 577-594.

Musial W and Bonnie R (2010) Large-scale Offshore Wind Power in the United States: Assessment of Opportunities and Barriers. See http://www.nrel.gov/docs/fy10osti/49229.pdf (accessed 12/07/2012).

Musial W and Butterfield S (2006) Energy from Offshore Wind. See http://www.nrel.gov/docs/fy06osti/39450.pdf (accessed 15/07/2012).

Quarton D, Rasmussen F, Argyriadis K and Nath C (1996) Wind turbine design calculations - the state of the art. Proceedings of the European Wind Energy Conference, Göteborg, Sweden, pp. 10-15.

Reese LC, Cox WR and Koop FD (1974) Analysis of laterally loaded piles in sand. Proceedings of the 6th Annual Offshore Technology Conference, Houston, TX, USA, pp. 473-484.

Reese LC, Cox WR and Koop FD (1975) Field testing and analysis of laterally loaded piles in stiff clay. Proceedings of the 7th Annual Offshore Technology Conference, Dallas, TX, USA, pp. 671-690.

Roddy DJ, Yu Y, Dufton DJ and Thornley P (2009) Lowcarbon energy solutions for an ecological island in China. Proceedings of the Institution of Civil Engineers - Energy 162(2): 85-95.

Rodenhausen M (2010) Soil Response of Offshore Wind Turbines. MSc thesis, University of Stuttgart, Stuttgart, Germany.

Saleem Z (2011) Alternatives and Modifications of Monopile Foundation or its Installation Technique for Noise Mitigation. See www.vliz.be/imisdocs/publications/223688. pdf (accessed 03/08/2012). 
Schaumann P and Böker C (2005) Can Tripods and Jackets Compete with Monopiles? See http://wind.nrel.gov/public/ SeaCon/Proceedings/Copenhagen.Offshore.Wind.2005/ documents/papers/Low_cost_foundations/P.Schaumann Can_jackets_and tripods_compete_with_monopile.pdf (accessed 06/08/2012).

Søren K, Poul-Erik M and Shimon A (2009) The Economics of Wind Energy. See http://www.windenergie.nl/sites/ windenergie.nl/files/documents/the_economics_of_ windenergy_ewea.pdf (accessed 17/07/2012).

Sørensen SPH, Brødbæk KT, Møller M, Augustesen AH and Ibsen LB (2009) Evaluation of load-displacement relationships for large-diameter piles in sand. In Proceedings of the 12th International Conference on Civil, Structural and Environmental Engineering Computing (Topping BHV, Costa Neves LF and Barros RC (eds)). Civil-Comp Press, Sterling, UK, paper 244.

Tarp-Johansen NJ (2005) Partial safety factors and characteristic values for combined extreme wind and wave load effects. Journal of Solar Energy Engineering 127(2): 242-252.

Tempel JV (2006) Design of Support Structures for Offshore Wind Turbines. PhD thesis, Delft University of Technology, Delft, the Netherlands.

Tempel JV and Molenaar DP (2002) Wind turbine structural dynamics - a review of the principles for modern power generation, onshore and offshore. Wind Engineering 26(2): 211-220.

Tong W (2010) Wind Power Generation and Wind Turbine Design. WIT Press, Southampton, UK.
Treehugger (2011) Is Direct Drive the Future? Wind Turbines Without Gears Are Lighter, Cheaper, More Reliable. See http://www.treehugger.com/renewable-energy/is-directdrive-the-future-wind-turbines-without-gears-are-lightercheaper-more-reliable.html (accessed 15/11/2012).

Tricklebank AH (2008) Briefing: Offshore wind energy - a challenge for UK civil engineering. Proceedings of the Institution of Civil Engineers - Energy 161(1): 3-6.

Vries WE (2007) UpWindProject.WP4: Assessment of Bottom-mounted Support Structure Types with Conventional Design Stiffness and Installation Techniques for Typical Deep Water Sites. See http://www.upwind.eu/pdf/Upwind_ WP4_D4.2.1_\%20Assessment $\% 20$ of $\% 20$ bottommounted $\% 20$ support $\% 20$ structure \% 20types.pdf (accessed $12 / 05 / 2012)$.

Vries WE (2011) UpWindProject.WP4: Support Structure Concepts for Deep Water Sites. See http://www.upwind.eu/ pdf/Final\%20report\%20WP4.2.pdf (accessed 10/08/2012).

Wiser R and Bolinger M (2011) 2010 Wind Technologies Market Report. US DOE, Office of Energy Efficiency and Renewable Energy, Washington, DC, USA.

WWEA (World Wind Energy Association) (2011) World Wind Energy Report 2010. See http://www.wwindea.org/home/ images/stories/pdfs/worldwindenergyreport2010_s.pdf (accessed 10/08/2012).

YFH (Yuanta Financial Holdings) (2011) Industry Update. Greater China: Energy. See http://ipreo.YUANTA.com/ NSightWeb_v2.00/Downloads/Files/29907.pdf (accessed 17/07/2012).
WHAT DO YOU THINK?

To discuss this paper, please email up to 500 words to the editor at journals@ice.org.uk. Your contribution will be forwarded to the author(s) for a reply and, if considered appropriate by the editorial panel, will be published as a discussion in a future issue of the journal.

Proceedings journals rely entirely on contributions sent in by civil engineering professionals, academics and students. Papers should be 2000-5000 words long (briefing papers should be 1000-2000 words long), with adequate illustrations and references. You can submit your paper online via www.icevirtuallibrary.com/content/journals, where you will also find detailed author guidelines. 